\title{
Importance of Pharmacotherapeutic Follow-Up in Odontopediatrics
}

\author{
Cristina Janeth Montañez-Sosa ${ }^{1}$, César Gaitán-Fonseca1, María Argelia López-Luna², \\ Carlos Bermúdez-Jiménez ${ }^{1}$, Jesús Luego-Ferreira1, Silverio Frausto-Esparza1, \\ Luis Alejandro Aguilera-Galavíz ${ }^{{ }^{*}}$
}

\author{
${ }^{1}$ Especialidad de Odontopediatría (CLIO) de la Unidad Académica de Odontología, Universidad Autónoma de Zacatecas, \\ (UAO/UAZ), Zacatecas, Mexico \\ ${ }^{2}$ Unidad Académica de Ciencias Químicas-QFB, Universidad Autónoma de Zacatecas, Zacatecas, Mexico \\ Email: *luisgalaviz_65@uaz.edu.mx
}

How to cite this paper: Montañez-Sosa, C.J., Gaitán-Fonseca, C., López-Luna, M.A., Bermúdez-Jiménez, C., Luego-Ferreira, J., Frausto-Esparza, S. and Aguilera-Galavíz, L.A. (2021) Importance of Pharmacotherapeutic Follow-Up in Odontopediatrics. Open Journal of Stomatology, 11, 1-13.

https://doi.org/10.4236/ojst.2021.111001

Received: November 11, 2020

Accepted: January 2, 2021

Published: January 5, 2021

Copyright $\odot 2021$ by author(s) and Scientific Research Publishing Inc. This work is licensed under the Creative Commons Attribution International License (CC BY 4.0).

http://creativecommons.org/licenses/by/4.0/

\section{(c) (i) Open Access}

\begin{abstract}
The most common cause of admission to the Pediatric Dentistry service is dental pain, active deafness and an oppressive sensation that is sometimes throbbing and burning. Pharmacotherapy in Pediatric Dentistry must be effective, safe, and rational in neonates, infants, and children. The pharmacotherapeutic follow-up of pediatric patients from Integral Clinic of the Odontopediatric Specialty (CLIO) and Kindergarten Clinic (CLIJANI), Autonomous University of Zacatecas (UAZ) was carried out. Through an observational, exploratory, and cross-sectional study, 23 patients from the Pediatric Dentistry Specialty Clinic (CLIO/UAO/UAZ) and 35 clinical records of patients from CLIJANI, from August 2019-2020, were analyzed. Prior authorization for the patient, an interview, and pharmacotherapeutic follow-up were performed, recording data on the indicated drug, the dose, and the schedule of use. On carrying out the interview on pharmacotherapy with the parents or guardians who accompany the patient, $91.3 \%$ of the pediatric patients were not administered pharmacological treatment. It was observed that there is no adequate adherence to the pharmacological treatment in pediatric patients.
\end{abstract}

\section{Keywords}

Tooth Pain, Analgesics, Antimicrobial Therapy

\section{Introduction}

From ancient times, humans have developed distinct methods for alleviating the pain produced by diseases. The prescription of medications has come together 
fundamentally in the clinical and odontological practice from past times. Medicines play an important role in the general status of the patient after performing an adequate diagnosis and complete evaluation in which the signs and symptoms of the disease are analyzed, in order to establish the pharmacological and nonpharmacological measures for each patient and for disease type. The medical prescription is considered a scientific, ethical, and legal act of great importance on the part of the Dentist [1]. Information on the pediatric use of drugs in some cases is incomplete. Studies on the utilization of medications in children are scarce; thus, it is important to be able to assess how medications are used, concretely analyzing their use in each situation, knowing the reactions that they can present, and the adherence that each patient presents to the treatment. Treatment adherence on the part of the patient is basic, as well as the indications of the patient's parents in terms of the patient's adequate taking of the medications and the pharmacological reactions, whether analgesic, antibiotic-therapeutic, or others [2] [3].

The most frequent pathologies in the oral cavity are of diverse origin and can give rise to lesions of the following types: infectious; traumatic; deficiency, or tumoral. Among infectious-type lesions, we find that these are produced in their majority by bacteria, viruses, or fungi caused by gingivitis, stomatitis, alveolitis, pulpitis, periodontitis, dentoalveolarabscesses, and ulcerations of diverse kinds. These produce pain and, in the greater part of cases, this is associated with inflammatory processes [4] [5] [6].

However, dental pain has as its main cause the presence of dental cavities due to harmful stimuli in the dentino-pulpar complex [5]. It affects children's quality of life and is an important indicator of the need for odontological care [7]. The use of analgesics, of non-opioid anti-inflammatory drugs that inhibit the biosynthesis of prostaglandins, and the use of antimicrobials comprises the treatment utilized under these conditions [8] [9] [10]. Lesions of the traumatic sort are accidental type, such as mechanical traumas or those that are the consequence of invasive-type odontological interventions such as exodontic procedures or diverse odonotological surgeries [11]. Another of the less frequent, but highly important, reasons present in pediatric patients are autoimmune lesions generally compromising the entire body, but sometimes these have repercussions in specific zones of the oral cavity, for example, scleroderma, which gives rise to gingival retractions that can cause retractile cheilitis, or subgingival lesions, and another situation such as avitaminosis (principally due to a deficit of vitamin $\mathrm{E}$ and B-complex), which predispose in their majority to inflammatory lesions and infections [12].

Pain is a common problem in Odontopediatrics; it is considered a symptom and obligates the search for its origin in order to correct it. The patients can experience pain caused by an abscess, a periodontal lesion, orthodontic apparatuses, or other diseases of the soft and hard oral tissues [13]. The management of pain should be individualized; according to the cause, severity, and chronicity, as 
well as in that the emotional state of the patient can, in some cases, give rise to disability according to the characteristics that it presents [14].

The analgesic action of NonSteroidal Anti-Inflammatory Drugs (NSAID) in Odontopediatrics is based fundamentally on inhibition of the enzyme CycloOXygenase 1 and 2 (COX1 and COX2) directly on the membrane of the inflammatory tissue with effects at the central and peripheral level, with the consequent reduction of the synthesis of thromboxanes and prostaglandins [15]. All NSAID are non-selective inhibitors of the enzyme cyclooxygenase, with the exception of acetylsalicylic acid [16].

According to the administration of antimicrobials to odontopediatric patients, $10 \%$ of the antibiotics that are prescribed are employed to treat oral-cavity infections, and with the therapeutic purpose (to eliminate the infection, diminish its severity, shorten its evolution, avoid general complications), in addition to their preventive purpose in patients with preexisting diseases (cardiological, non-transmittable chronic diseases, and immunocompromised patients) [17]. In Odontopediatrics, first-choice antibiotics are penicillins; among these, Amoxicillin, which presents bactericidal action and good absorption by oral route $(75 \%-90 \%)$, can be administered with the ingestion of food. Its half-life is greater than the remainder of the penicillins; its mechanism of action is through inhibition of the action of the peptidases and carboxypeptidases, impeding the synthesis of the bacterial cell wall [18]. Amoxicillin is associated with irreversible betalactamase inhibitors, such as clavulanic acid or the sulbactam pivoxyl; it permit the treatment of infections due to betalactamase-producing bacteria and is the drug-ofchoice for patients who have been treated systemically, but who have not received adequate local treatment (chamber opening, drainage), with the persistence of the infectious symptoms [19]. The extensive dissemination of resistance of antibiotics in pediatric patients obliges us to effect very much more prudent changes in their prescription, such as their use solely when they are useful for the patient, bearing in mind the possible bacterial pathogens implicated and the levels of resistance of each level, with the minimal impact possible on the respiratory and intestinal flora and adequate drug doses and duration to ensure efficacy, tolerance, and adherence to the treatment. One of the most important adverse effects of the penicillins is hypersensitivity, which can induce effects ranging from the most simple skin eruption to anaphylactic shock. Allergic reactions to Penicillin are described in $0.7 \%-10 \%$ of exposed individuals, and anaphylactic reactions in fewer than $0.004 \%-0.2 \%$. Therefore, it is contraindicated in individuals with antecedents of anaphylaxis, urticaria, or eruptions immediately after the administration of Penicillin [20]. Pharmaoresistance to antimicrobials is a worldwide, ever increasing problem generated by the indiscriminate and abusive use of penicillins [21]. Thus, educative measures on the rational use of antimicrobials are necessary, in addition to the requirement for measures directed by medical health personnel to the parents of the children involved [22] [23]. The most utilized antimicrobials in Odontopediatrics are presented in Table 1. 
NonSteroidal Anti-Inflammatory Drugs (NSAID), as the pharmacological treatment-of-choice in Odontopediatrics in dental pain [24], is indicated because of their analgesic action; their mechanism of action comprises the inhibition of the cyclooxygenase enzyme at the central and peripheral level, after the reduction of prostaglandin and thromboxane synthesis [25]. The most utilized analgesics are depicted in Table 2. At present, there are no fixed rules for the calculation of the optimal dose of a drug, in that these dates are mainly based on the calculation associated with the Body Weight (BW) and not with other variables [28] [29]. The multiple approximations that have been described reveal the true complexity of this problem. Utilization of the age of the child as reference for the adjustment of the dose can cause serious errors on not taking into consideration the wide variations in weight of children within the same age group [30] [31].

Medication reconciliation is the process of creating the most precise list possible of all the drugs that a patient takes. The substantial amount of drugs that are currently available and the variety of indications for their use can render the process very difficult to prescribe or administer any drug necessary for dental treatment [32] [33] [34]. A precise history of medications allows the oral caregiver to evaluate the general health and disease status of a patient, the effect that medications exert on the dental treatment, and the possible contradictions and synergic or antagonist effects among the medications [35]. There are two important tasks in order to obtain successful results in medication reconciliation to determine the medication that the patient is taking at present, and to ask whether the patient has some allergy to drugs, foods, or other substances [36] [37]. If the purpose of the drug is not included on the label of the container, the patients

Table 1. Pediatric NSAID doses and the antimicrobials most utilized by oral route in Odontopediatrics [27].

\begin{tabular}{ccl}
\hline \multicolumn{3}{c}{ Antibiotics } \\
\hline Amoxicillin & Solution 125,250 , and $500 \mathrm{mg} / 5 \mathrm{ml}$ & $\begin{array}{l}20-50 \mathrm{mg} / \mathrm{kg} / \text { day, divided into 8-hour } \\
\text { intervals }\end{array}$ \\
Azithromycin & Suspension $200 \mathrm{mg} / \mathrm{ml}$, tab. $500 \mathrm{mg}$ & $12 \mathrm{mg} / \mathrm{kg} / \mathrm{day}$, unique dose for 5 days \\
Cephalexin & Solution 125,250, or $500 \mathrm{mg} / 5 \mathrm{ml}$ & $25-50 \mathrm{mg} / \mathrm{kg} /$ day, divided into 4 doses \\
Erythromycin & Solution 125,250, or $500 \mathrm{mg} / 5 \mathrm{ml}$ & $30-50 \mathrm{mg} / \mathrm{kg} / \mathrm{day}$, divided into 4 doses \\
Penicillin $\mathrm{V}_{-}$ & Solution $400,000 \mathrm{U} / 5 \mathrm{ml}$ & $\begin{array}{l}25,000-90,000 \mathrm{U} / \mathrm{kg} / \text { day, of } 6 / 6 \text { or } 8 / 8 \\
\text { hours }\end{array}$ \\
\hline
\end{tabular}

Table 2. Pediatric doses of NSAID most utilized via oral route [26].

\begin{tabular}{ccc}
\hline Medication & Dose & Schedule \\
\hline Ibuprofen & $5-10 \mathrm{mg} / \mathrm{kg}$ of weight & Every $6-8$ hours \\
Acetylsalicylic acid & $10-15 \mathrm{mg} / \mathrm{kg}$ of weight & Every $4-6$ hours \\
Diclofenac & $0.5-1.5 \mathrm{mg} / \mathrm{kg}$ of weight & Every $6-8$ hours \\
Ketorolac & $0.1-0.2 \mathrm{mg} / \mathrm{kg}$ of weight & Every 6 hours \\
Metamizole & $20-40 \mathrm{mg} / \mathrm{kg}$ of weight & Every $6-8$ hours \\
\hline
\end{tabular}


should be asked why they are taking the drug. Many drugs that have been on the market for a long time are utilized to treat diseases for which they were not originally prescribed [38] [39]. The objective of medication reconciliation is to diminish possible errors in medication (Table 3 ), and possible medication interactions, in addition to detecting risks to the patient's health [41] [42]. This is conducted without judging the medical practice or questioning individual clinical decisions, but instead to detect and correct possible Errors of Prescription (EP) that could go undetected during the clinical practice [43] [44] [45] [46].

The objective of this work was the pharmacotherapeutic follow-up associated and supported by current clinical guidelines for the management of pediatric patients presenting at the UAO/UAZ Odontopediatric Clinic, In addition, the aim was the registration of each patient individually to describe schemas and protocols in relation to the rational use of antimicrobial and NonSteroidal Anti-Inflammatory Drugs (NSAID) in pediatric patients.

Table 3. Types of errors in medication [40].

\begin{tabular}{|c|c|}
\hline Medication reconciliation error & $\begin{array}{l}\text { Explanation of medication } \\
\text { reconciliation error }\end{array}$ \\
\hline Omission of the medication & $\begin{array}{l}\text { The patient was taking a necessary } \\
\text { medication and this was not prescribed, } \\
\text { without there being an explicit or implicit } \\
\text { clinical justification for this }\end{array}$ \\
\hline $\begin{array}{l}\text { Different dose, route, or frequency of the } \\
\text { administration of a drug }\end{array}$ & $\begin{array}{l}\text { The dose, route, and frequency is modified of } \\
\text { a medication that the patient was taking, } \\
\text { without there being a clinical justification, } \\
\text { explicit or explicit, for this }\end{array}$ \\
\hline Incomplete prescription & $\begin{array}{l}\text { The presence of the chronic treatment is } \\
\text { carried out in an incomplete manner and } \\
\text { requires clarification }\end{array}$ \\
\hline Incorrect medication & $\begin{array}{l}\text { A new medication is prescribed without } \\
\text { clinical justification, confusing the medication } \\
\text { with another that the patient took and that } \\
\text { has not been prescribed }\end{array}$ \\
\hline $\begin{array}{l}\text { Initiation of medication (commission } \\
\text { discrepancy) }\end{array}$ & $\begin{array}{l}\text { A treatment is initiated that the patient did not } \\
\text { take previously, and there is no clinical } \\
\text { justification explicit or implicit, } \\
\text { for the initiation }\end{array}$ \\
\hline Duplicity & $\begin{array}{l}\text { The patient presents duplicity between the } \\
\text { prior medication and the new prescription }\end{array}$ \\
\hline Interaction & $\begin{array}{l}\text { The patient presents a chemically relevant } \\
\text { interaction between the prior medication } \\
\text { and the new prescription }\end{array}$ \\
\hline Maintenance of incorrect medication & $\begin{array}{l}\text { The contraindicated chronic medication } \\
\text { continued in the new clinical situation of } \\
\text { the patient }\end{array}$ \\
\hline
\end{tabular}




\section{Material and Methods}

An observational, exploratory, transversal-type study was developed. The study population was recruited in Integral Clinic of the Odontopediatric Specialty (CLIO) of the Academic Unit of Odontology (UAO) of the Autonomous University of Zacatecas (UAZ), from August 2019 to August 2020. In the selection criteria included: patients between two and twelve years, presence with or without pain, require pharmacological treatment (antibiotic and analgesic) and accept to participate in the study. For the exclusion criteria: patients who do not accept to participate in the study. Patients lose the evaluation instrument, patients do not return for an appointment and uncooperative patient. Twentythree patients came to clinical care were included in the study population. The follow-up time was per 15 days in each patient. In the other hand a retrospective review of the clinical files of 35 CLIJANI patients, for whom authorization was requested to consult with and determine whether the variables and the criteria studied in our work are considered in the practice.

\section{Results}

\subsection{Study Population by Gender and Age of the Patients}

There were 23 children who attended the Care Clinic for diverse reasons in the Odontopediatrics Speciality Program, among whom $30.4 \%$ were feminine gender and $69.6 \%$, masculine gender. With regard to the patient's age, we are able to observe that the most frequent mean age for the study group was 7.56 years, the most frequent age group was 9 years with five patients, and six patients were between the ages of 3 and 5 years. One of the main reasons for consultation with the Odontopediatrician is the presence of cavities and, in many cases, pain; only $34.7 \%$ of the study group referred pain, while the remaining $65.3 \%$ manifested the absence of this.

\subsection{Pharmacological Interview}

On carrying out the interview on pharmacotherapy with the parents or guardians who accompany the patient, $91.3 \%$ of the pediatric patients were not administered pharmacological treatment. The latter was administered only to $8.7 \%$, which corresponds to two patients. These patients referred the administration of some medication related to oro-dental problems prior to knowing the patient's diagnosis.

\subsection{Dental Diagnosis of the Patients}

With regard to distribution in absolute values according to the dental diagnosis referred by the Medical Residents in the Odontopediatrics Specialty of the $\mathrm{Au}$ tonomous University of Zacatecas, it is reported that $47.08 \%$ of the patients presented pulp necrosis, $26.09 \%$ presented irreversible pulpitis, and the remaining $26.09 \%$ presented dental diagnoses such as acute periapical periodontal abscess, cellulitis, apical perforation, the persistence of teeth temporary and dental avul- 
sion (Table 4).

\subsection{Post-Odontological Pharmacological Treatment}

The pharmacological treatment-of-choice prescribed by the Medical Residents of the Ondotology Specialty was antibiotic therapy in $91.30 \%$ of cases, while in $8.70 \%$, the administration of an analgesic was indicated. Among the antimicrobials prescribed, in $34.72 \%$ of patients an Amoxicillin suspension of $250 \mathrm{mg} / \mathrm{ml}$ was indicated, while $26.04 \%$ of patients were prescribed a suspension of Amoxicillin with clavulanic acid $250 \mathrm{mg} / 62.5 \mathrm{mg} / 5 \mathrm{ml}$. On the other hand, it was observed that $8.68 \%$, equivalent to two patients, were prescribed an analgesic, indicating to us that the majority of patients who enter the Odontopediatric Specialty Clinic for a diagnosis present dental infections (Table 5).

\subsection{Pharmaco Therapeutic Follow-Up (PTF)}

One important aspect for the success of any treatment is following the instructions precisely and, needless to say, the adequate administration of the medications. In order to know the degree to which the patients follow the indications for the pharmacological treatment, the parents or guardians were provided with a registration sheet on which the time and the number of days that they followed the indications were noted. According to the latter, of the 21 patients who were

Table 4. Distribution of the patients according to the diagnosis.

\begin{tabular}{ccc}
\hline Diagnosis & Number & Pathology \\
\hline Pulp necrosis & 11 & Pulpar \\
Irreversible pulpitis & 6 & Pulpar \\
Acute periapical abscess & 1 & Pulpar \\
Periodontal abscess & 1 & Periodontal \\
Cellulitis & 1 & Pulpar \\
Apical perforation & 1 & Pulpar/periodontal \\
Persistence of teeth & 1 & Antibiotic prophylaxis (idiopathic \\
temporary & 1 & pulmonary hypertension) \\
Dental avulsion & 23 & Trauma \\
Total & & \\
\hline
\end{tabular}

Table 5. Distribution of patients according to the post-Dx pharmacological treatment.

\begin{tabular}{cc}
\hline Indicated medication & Patients \\
Amoxicillin tab. $250 \mathrm{mg}$ & 4 \\
Amoxicillin/Clavulanic acid susp. $250 / 62.5 \mathrm{ml}$ & 6 \\
Amoxicillin susp. $250 / 5 \mathrm{ml}$ & 8 \\
Amoxicillin susp. $500 \mathrm{ml} / 5 \mathrm{ml}$ & 2 \\
Amoxcillin tab. $500 \mathrm{mg}$ & 1 \\
Paracetamol $60 \mathrm{mg} / \mathrm{kg} / \mathrm{day}$ & 2 \\
\hline
\end{tabular}


indicated an antibiotic, $78.26 \%$ of these complied with the indications for a 7 -day time period; in addition, $4.34 \%$ corresponds to one patient for 5 days, one patient for 3 days, and one patient was administered a unique dose. In the case of analgesics, the two patients who were indicated the latter complied with the prescribed treatment for 3 days or with its suspension on disappearance of the pain.

\subsection{Dental Pharmacology in Patients with Pathologies}

With respect to Pathology (Table 6), three of the patients presented interventricular communication; one had idiopathic pulmonary hypertension, and one, cardiac murmur. The systemic afflictions of the five patients, as well as the data provided by their clinical history, in addition to the indications in relation to the oro-dental diagnosis for each of the patients, were taken into account. Only one of these five patients was found under treatment; therefore, in coordination with the Pediatric Cardiologist, prophylaxis was established with antibiotics. These patients were referred to the Pediatric Cardiologist for their assessment, prior to treatment and to the administration of the medications, in order to establish a coordinated treatment.

Table 6. Patients with systemic afflictions, treatment and diagnosis of oro-dental diseases.

\begin{tabular}{|c|c|c|c|}
\hline \multicolumn{4}{|c|}{ Patients with systemic compromise in Pharmacological Tx } \\
\hline $\begin{array}{l}\text { Systemic } \\
\text { diagnosis }\end{array}$ & $\begin{array}{l}\text { Drug indicated } \\
\text { by the treating } \\
\text { physician }\end{array}$ & $\begin{array}{l}\text { Drug indicated by the } \\
\text { Medical Resident in } \\
\text { Odontopediatrics }\end{array}$ & Dental diagnosis \\
\hline $\begin{array}{l}\text { Idiopathic } \\
\text { pulmonary } \\
\text { hypertension }\end{array}$ & $\begin{array}{l}\text { Slidenafil } 1 / 2 \text { tab. } 50 \mathrm{mg} \\
\text { Spinonolactone tab. } 25 \\
\text { mg Montelukast tab. } 5.0 \\
\text { mg }\end{array}$ & $\begin{array}{l}\text { Amoxicillin } 250 \\
\mathrm{mg} / 5 \mathrm{ml} \\
\text { Antibiotic prophylaxis } \\
\text { (authorized by the } \\
\text { Pediatric Cardiologist) }\end{array}$ & $\begin{array}{l}\text { Persistence of } \\
\text { tooth temporary }\end{array}$ \\
\hline $\begin{array}{l}\text { Interventricular } \\
\text { communication }\end{array}$ & Without medical Tx & $\begin{array}{l}\text { Amoxicillin with } \\
\text { Clavulanic acid } 500 \\
\text { mg/250ml (Referred to } \\
\text { consultation with the } \\
\text { Pediatric Cardiologist) }\end{array}$ & Pulp necrosis \\
\hline $\begin{array}{l}\text { Interventricular } \\
\text { communication }\end{array}$ & Without medical Tx & $\begin{array}{l}\text { Amoxicillin } 250 \\
\mathrm{mg} / 5 \mathrm{ml} \text { (Referred to } \\
\text { consultation with the } \\
\text { Pediatric Cardiologist) }\end{array}$ & Pulp necrosis \\
\hline $\begin{array}{l}\text { Interventricular } \\
\text { communication }\end{array}$ & Without medical Tx & $\begin{array}{l}\text { Amoxicillin tab. } \\
250 \mathrm{mg}\end{array}$ & Irreversible pulpitis \\
\hline Cardiac murmur & Without medical Tx & $\begin{array}{l}\text { Amoxicillin } 250 \\
\mathrm{mg} / 5 \mathrm{ml} \text { (Referred to } \\
\text { consultation with the } \\
\text { Pediatric Cardiologist) }\end{array}$ & Irreversible pulpitis \\
\hline
\end{tabular}




\subsection{Pharmacotherapeutic Follow-Up in CLIJANI/UAO-UAZ Clinics}

With the purpose of identifying whether there are some pharmacological-followup protocols at the UAO/UAZ Kindergarten Clinics, a review was conducted of the clinical histories of 35 children in attendance during the August 2019-July 2020 academic school-year cycle, taking into consideration the same variables of the UAO/UAZ Odontopediatric Specialty Clinic, that is, children aged between 4 and 5 years $(77.1 \%)$ and a small proportion of care for three children aged 2 years and one aged 7 years, with an average age of 4.68 years and a Standard Deviation (SD) of \pm 0.9 . It was reported that $71.42 \%$ of patients presented grades 1 and 2 caries, $8.57 \%$ had pulp necrosis, and the remaining $20.01 \%$ presented dental diagnoses such as irreversible pulpitis, localized gingivitis, fluorosis, malocclusion, and persistence of the temporary dental organ.

According to the reason for the consultation and the presence of pain, only $6 \%$ of the children seen referred pain, while the remaining $94 \%$ did not cite the latter. According to the clinical histories, highlighting medication reconciliation, none of the patients received pharmacological treatment or were at this timeunder some medicinal therapy, and none had some disease of systemic origin, where it was observed that the patients were under pharmacotherapeutic follow-up.

\section{Conclusions}

Pediatric patients are distinct from adult patients in their metabolic behavior and in their response to a certain medication. This makes it necessary to determine the exact dose of the drug, the administration route, the duration, and interactions with concomitant therapy and, of course, the registration of any adverse reaction presenting during the administration of the treatment.

In the work carried out, it was observed that there is no adequate adherence to the pharmacological treatment in pediatric patients who presented at the CLIO of the UAO/UAZ, in that among $100 \%$ of the medicated patients; only $2 \%$ complied with their pharmacological treatment. That is to say, $2 \%$ followed the schedule and the frequency indicated in their pharmacological treatment, indicating to us that the mothers and guardians responsible for the patients did not have a control of the schedule and frequency at the time of complying with the taking of each medication indicated. These findings are in agreement with what has been reported; there is a disconnection from the indications of the pharmacological treatment, with medications being taken outside of the time indicated, or early suspension prior to the schedule for completing the schema, this generating microbial resistance, diminishing or modifying the response of the patient to the medication. It is of the utmost importance for the Odontopediatrician to perform medication reconciliation in each of the patients with or without medical treatment, as well as vigilance of the patients' pharmacological treatment.

\section{Acknowledgements}

The Investigation Project was carried out thanks to the collaboration of the Odon- 
topediatric Specialty Clinics (CLIO) and of the Kindergarten (CLIJANI) of the Academic Unit of Odontology of the Autonomous University of Zacatecas, Zacatecas City, Mexico, which permitted the revision of patients and their pharmacological follow-up in Pharmacology (CLIO), as well as the retrospective review of the clinical files (CLIJANI).Our thanks go to Consejo Nacional de Ciencia y Tecnología (CONACyT) for the grant for postgraduate studies to Cristina Jareth Montañez-Sosa, postgraduate student of the UAO/UAZ Odontopediatric Specialty.

\section{Conflicts of Interest}

The authors declare no conflicts of interest regarding the publication of this paper.

\section{References}

[1] Norma Oficial Mexicana NOM-220-SSA1-2016 Instalación Operación de la Farmacovigilancia. Secretaría de Salud (19 jun, 2019) (citado 4 dic. 2019).

[2] Orozco, S.M., García, A.Y., Pilchard, R.C., Zapata, M.J. and Isirodina, E.M. (2016) Single Dose of Diclofenac or Meloxicam for Control of Pain, Facial Swelling, and Trismus in Oral Surgery. Medicina Oral, Patologia Oral y Cirugia Bucal, 21, e127e134. https://doi.org/10.4317/medoral.20925

[3] Lasagna, L., et al. (2014) GRACIAS Farmacología Clínica: Actividades y Enseñanza. OMS, Serie de InformesTécnicos, Ginebra, No. 446, 18-21.

[4] Phillips, I. (2015) Withdrawal of Growth-Promoting Antibiotics in Europe and Its Effects in Relation to Human Health. International Journal of Antimicrobial Agents, 30, 101-107. https://doi.org/10.1016/j.ijantimicag.2007.02.018

[5] Kim, J.H. and Gallis, H.A. (2014) Observations on Spiraling Empiricism: Its Causes, Allure, and Perils, with Particular Reference to Antibiotic Therapy. The American Journal of Medicine, 87, 201-206. https://doi.org/10.1016/S0002-9343(89)80697-7

[6] Ligon, B.L. and Florey Sir, H.W. (2014) The Force behind the Development of Penicillin. Seminars in Pediatric Infections Diseases, 15, 109-114. https://doi.org/10.1053/j.spid.2004.04.001

[7] Doern, G.V. (2014) Optimizing the Management of Community-Acquired Respiratory Tract Infections in the Age of Antimicrobial Resistance. Expert Review of Anti-Infective Therapy, 4, 821-835. https://doi.org/10.1586/14787210.4.5.821

[8] Huang, J.Q., Sridhar, S. and Hunt, R.H. (2015) Role of Helicobacter pylori Infection and Non-Steroidal Anti-Inflammatory Drugs in Peptic-Ulcer Disease: A Meta-Analysis. The Lancet, 35, 14-22. https://doi.org/10.1016/S0140-6736(02)07273-2

[9] Salunke, S., Giacoia, G. and Tuleu, C. (2012) The STEP (Safety and Toxicity of Excipients for Pediatrics) Database. Part 1-A Need Assessment Study. International Journal of Pharmacology, 435, 101-111. https://doi.org/10.1016/j.ijpharm.2012.05.004

[10] Gutiérrez, J.S., Wiesenthal, E.F., Koehler, B.S., Halterman, M.D., Jill, S.J. and Asthma, H. (2014) Discrepancies between Medical Record Data and Parent Reported Use of Preventive Asthma Medications. Journal of Asthma, 51, 446-450. https://doi.org/10.3109/02770903.2013.878351

[11] O'Connor, J.P., Hartling, L.O., Samina, A., Dryden, D.M., Johnson, D.W., Plint A.C., McGrath, P.J. and Drendel, A.L. (2018) Effect of Non-Steroidal Anti-Inflam- 
matory Drugs on Bone Healing. Macedonian Journal of Medical Sciences, 6, 14861491.

[12] Désiré, A.P., Soyeidan, A.S., Pauline, L., Coulibaly, N.T. and Struillou, X.C. (2018) Twenty Years of Full-Mouth Disinfection: The Past, the Present and the Future. The Open Dentistry Journal, 12, 435-442. https://doi.org/10.2174/1874210601812010435

[13] Fleming, P.S., Abazi, B.D. and Mihani, J.D. (2016) Prescription of Antibiotics for Periodontal Disease among Dentists in the Region of Tirana. Journal of Medical Sciences, 5, 365-382.

[14] Allan, J.D., Eliopoulos, G.M. and Moellering Jr., R.C. (1987) Antibiotics: Future Directions by Understanding Structure-Function Relationships. In: Root, R.K., Trunkey, D.D., Sande, M.A., Eds., New Surgical and Medical Approaches in Infectious Diseases, Vol. 6, Churchill Livingstone, New York, 263-284.

[15] Billstein, S.A. (2014) How the Pharmaceutical Industry Brings an Antibiotic Drug to Market in the United States. The Open Dentistry Journal, 11, 2679-2682.

https://doi.org/10.1128/AAC.38.12.2679

[16] Paulozzi, L.J., Mack, K.A., Hockenberry, J.M., Division of Unintentional Injury Prevention, National Center for Injury Prevention and Control, CDC (2012) Vital Signs: Variation among States in Prescribing of Opioid Pain Relievers and Benzodiazepines-United States, 2012. MMWR Morbidity and Mortality Weekly Report, 63, 563-568.

[17] Agnihotry, H.A., Fedorowicz, Z., Zuuren, E.J., Farman, A.G. and Al-Langawi, J.H. (2016) Antibiotic Use for Irreversible Pulpitis. Cochrane Database Systematic Reviews, 5, CD004969. https://doi.org/10.1002/14651858.CD004969.pub4

[18] Zeitoun, I.M. and Dhanarajani, P.J. (2018) Cervical Cellulitis and Mediastinitis Caused by Odontogenic Infections: Report of Two Cases and Review of Literature. Journal of Oral and Maxillofacial Surgery, 53, 203-208. https://doi.org/10.1016/0278-2391(95)90404-2

[19] Finley, G.A., Kristjánsdóttir, O.L. and Forgeron, P.A. (2015) Cultural Influences on the Assessment of Children's Pain. Pain Research \& Management, 14, 33-37. https://doi.org/10.1155/2009/763031

[20] Demoly, P. and Hillaire-Buys, D. (2004) Classification and Epidemiology of Hypersensitivity Drug Reactions. Immunology and Allergy Clinics of North America, 24, 345-356. https://doi.org/10.1016/j.iac.2004.03.010

[21] Talhari, C., Lauceviciute, I., Enderlein, E., Ruzicka, T. and Homey, B. (2015) COX2-Selective Inhibitor Valdecoxib Induces Severe Allergic Skin Reactions. The Journal of Allergy and Clinical Immunology, 115, 1089-1090. https://doi.org/10.1016/j.jaci.2004.12.1135

[22] Calvo, J. and Martínez-Martínez, L. (2014) Mecanismos de acción de los antimicrobianos. Enfermedades Infecciosas y Microbiología Clínica, 27, 44-52. https://doi.org/10.1016/j.eimc.2008.11.001

[23] García, A.G. (2014) Manual de prescripción racional de fármacos. Índice farmacológico de especialidades farmacéuticas. Edimsa, Madrid.

[24] Rivera-Ordóñez, A. (2014) AINES: Su mecanismo de acción en el sistema nervioso central. Revista Mexicana de Anestesiologia, 29, 36-40.

[25] Palmer, N.O.A., Martin, M.V., Pealing, R. and Ireland, R.S. (2015) Pediatric Antibiotic Prescribing by General Dental Practitioners in England. International Journal of Paediatric Dentistry, 11, 242-248. https://doi.org/10.1046/j.1365-263X.2001.00280.x

[26] (2013-2014) Intercon, Manual de prescripción racional de fármacos. Índice de espe- 
cialidades farmacéuticas. Edimsa, Madrid.

[27] Granizo, J.J., Giménez, M.J., Bascones, A. and Aguilar, L. (2014) Ecological Impact of Antibiotic Treatment of Dental Infections. Revista Española de Quimioterapia, 19, 14-20.

[28] Jayadev, M.T., Karunakar, P., Vishwanath, B., Soumya, S., Siddhartha, P. and Chaitanya, B. (2014) Knowledge and Pattern of Antibiotic and Non Narcotic Analgesic Prescription for Pulpal and Periapical Pathologies-A Survey among Dentists. Journal of Clinical and Diagnostic Research, 8, 10-14. https://doi.org/10.7860/JCDR/2014/9645.4536

[29] Flores, J.E., Ochoa, M.D., Romero, J. and Barraza, H. (2014) Analgésicos en Odontología: Resultados de una encuesta sobre su uso clínico. Revista de la Asociación Dental Mexicana, 71, 171-177.

[30] Bolfoni, M.R., Pappen, F.G., Pereira-Cenci, T. and Jacinto, R.C. (2018) Antibiotic Prescription for Endodontic Infections: A Survey of Brazilian Endodontists. International Endodontic Journal, 51, 148-156. https://doi.org/10.1111/iej.12823

[31] Golianu, B., Krane, E.J., Galloway, K.S. and Yaster, M. (2001) The Assessment and Management of Acute Pain in Infants, Children and Adolescents. Pediatrics, 108, 793797. https://doi.org/10.1542/peds.108.3.793

[32] Berde, C.B. and Sethna, N.F. (2016) Analgesic for the Treatment of Pain in Children. The New England Journal of Medicine, 347, 1094-1103. https://doi.org/10.1056/NEJMra012626

[33] (2017) The Importance of Medication Reconciliation in the Dental Practice, National Center for Health Statistics, Health, United States, 2016: With Chartbook on Long-Term Trends in Health, Table 79, p. 293. Hyattsville.

[34] Thomas, E.J., Studdert, D.M., Burstin, H.R., et al. (2014) Incidence and Types of Adverse Events and Negligent Care in Utah and Colorado. Medical Care, 38, 261-271. https://doi.org/10.1097/00005650-200003000-00003

[35] Montagne, F., Jacinto, R.C., Correa, F.G., Scheffer de, M.V., Grecca, F.S. and Gomes, B.P. (2018) Beta-Lactamic Resistance Profiles in Porphyromonas, Prevotella, and Parvimonas Species Isolated from Acute Endodontic Infections. Journal of Endodontics, 40, 339-344. https://doi.org/10.1016/j.joen.2013.10.037

[36] Dawoud, B.E. and Yates, J.M. (216) Drug Interactions in General Dental Practice: Considerations for the Dental Practitioner. British Dental Journal, 216, 15-23. https://doi.org/10.1038/sj.bdj.2013.1237

[37] (2014) Medication Reconciliation at Discharge: A Review of the Clinical Evidence and Guidelines. Rapid Response Report, Summary with Critical Appraisal.

[38] Institute for Safe Medication Practices Canada (2015) Medication Reconciliation in Acute Care. Getting Started Kit. Safer Healthcare Now.

[39] Rodríguez, G. and Rosich, I. (2014) Conciliación de la medicación. Elementos básicos del abordaje de la medicación en el paciente crónico: Información al paciente, conciliación, revisión adherencia. Cap. 2, SEFAP.

[40] (2016) How to Guide: Prevent Adverse Drug Events by Implementing Medication Reconciliation. Institute for Healthcare Improvement, Cambridge.

[41] Pronovost, P., Weast, B., Schwarz, M., Wyskiel, R.M., Prow, D., Milanovich, S.N. and Lipsett, P. (2015) Medication Reconciliation: A Practical Tool to Reduce the Risk of Medication Errors. Journal of Critical Care, 18, 201-205. https://doi.org/10.1016/j.jcrc.2003.10.001

[42] Norma Oficial Mexicana NOM-073-SSA1-2015 Estabilidad de fármacos y medica- 
mentos, así como de remedios herbolarios. Secretaría de Salud (7 mayo, 2016) (citado 4 dic. 2017).

[43] Van Eekeren, R., Rolfes, L., Koster, A.S., et al. (2018) What Future Healthcare Professionals Need to Know about Pharmacovigilance: Introduction of the WHO PV Core Curriculum for University Teaching with Focus on Clinical Aspects. Drug Safety, 41, 1003-1101. https://doi.org/10.1007/s40264-018-0681-z

[44] Planells-del Pozo, P., Barra-Soto, M.J. and Santa Eulalia-Troisfontaines, E.S. (2006) Antibiotic Prophylaxis in Pediatric Odontology. An Update. Medicina Oral, Patologia Oral y Cirugia Bucal, 11, E352-E357.

[45] Segura-Egea, J.J., Gould, K., Şen, B.H., et al. (2017) Antibiotics in Endodontics: A Review. International Endodontic Journal, 50, 1169-1184.

https://doi.org/10.1111/iej.12741

[46] Segura-Egea, J.J., Gould, K., Şen, B.H., et al. (2018) European Society of Endodontology Position Statement: The Use of Antibiotics in Endodontics. International Endodontic Journal, 51, 20-25. https://doi.org/10.1111/iej.12781 